\section{First record of two tubuliferan and four terebrantian species of Thysanoptera (Insecta) from northeastern India}

\author{
Kh. Bala ${ }^{1}$, O. Tarunkumar Singh ${ }^{2}$, H. Taptamani \\ ${ }^{3}$ \& R. Varatharajan ${ }^{4}$ \\ 1,2,3,4 Centre of Advanced Study in Life Sciences \\ Manipur University, Imphal, Manipur 795003, India \\ Email: ${ }^{1}$ balakhkm@gmail.com, ${ }^{2}$ otsingh2010@gmail.com, \\ ${ }^{3}$ tapta18jan@gmail.com, ${ }^{4}$ rvrajanramya@rediffmail.com \\ (corresponding author)
}

The order Thysanoptera popularly known as thrips or fringe wings are known to be of considerable significance as they feed on food and horticultural plants and also due to their ability to act as vectors of some bacterial, fungal and viral diseases of plants (David \& Ananthakrishnan 2004). In spite of extensive taxonomic contributions mainly by Ananthakrishnan \& Sen (1980) and Bhatti (1994), there is a paucity of information on thrips of northeastern India. All specimens were collected during the present study from Manipur and Nagaland. Prior to this, their occurrences were known only from a few Southeast Asian countries. Specimens collected in the present study are deposited in the insect museum of the Department of Life Sciences, Manipur University.

Date of publication (online): 26 November 2012

Date of publication (print): 26 November 2012

ISSN 0974-7907 (online) | 0974-7893 (print)

Editor: K.G. Sivaramakrishnan

Manuscript details:

Ms \# 03052

Received 03 January 2012

Final received 12 May 2012

Finally accepted 02 September 2012

Citation: Bala, K., O.T. Singh, H. Taptamani \& R. Varatharajan (2012). Firs record of two tubuliferan and four terebrantian species of Thysanoptera (Insecta) from northeastern India. Journal of Threatened Taxa 4(14) 3369-3372.

Copyright: (c) Kh. Bala, O. Tarunkumar Singh, H. Taptamani \& R Varatharajan 2012. Creative Commons Attribution 3.0 Unported License. JoTT allows unrestricted use of this article in any medium for non-profit purposes, reproduction and distribution by providing adequate credit to the authors and the source of publication.

Acknowledgements: The authors thank the Ministry of Environment and Forest, New Delhi for the financial support and to the Head, Department of Life Sciences, Manipur University for the laboratory facilities.

urn:Isid:zoobank.org:pub:B8555A58-0C76-46F0-9EA2-D7906177E907

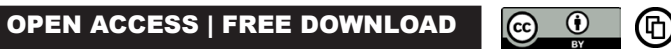

The present new records will hopefully motivate future workers to engage in indepth survey and taxonomic explorations of thrips in the north-east, a biodiversity hotspot.

\section{Suborder: Tubulifera}

Family: Phlaeothripidae

\section{Baenothrips asper (Bournier, 1963)}

Transithrips asper Bournier, 1963, Publ. Cult. Co. Diam. Angola, 63: 81.

Transithrips asper Bournier-Ananthakrishnan, 1966, Bull.Ent., 7: 11.

Baenothrips asper (Bournier) - Mound, 1972. Aust. J. Zool., 20: 92.

Baenothrips asper (Bournier) - Ananthakrishnan \& Sen, 1980, Zool. Surv. India, Handbk. Ser., 1: 82 \& 145.

Baenothrips asper (Bournier) - Bhatti, 2002, Oriental Insects, 36: 1-28.

Specimen studied: 12 females, 25.ii.2002, 1400m, ex. mixed leaf litter, Khuzama (Nagaland), (MU/LSD No. B/Myco/17) (Table 1 and Image 1).

Distribution: India [Eastern Ghat (apterous form), Nagaland (macropterous form - new record)], Angola, Luanda, Taiwan.

Comments: As early as 1963, Bournier described the macropterous form of Baenothrips asper (= Transithrips asper) from Angola, Africa. Subsequently, occurrence of $B$. asper was reported from India (Ananthakrishnan 1966) and Taiwan (Kudo 1978) based on the apterous individuals. However, Bhatti (2002) on examining the Indian materials felt that there could be two different species of Baenothrips including that of apterous $B$. asper, but the identity of the latter did not match with the winged form of Angolan species. Recently, during the survey in Nagaland, a dozen individuals of the macropterous form of $B$. asper were collected from mixed leaf litter. The characters of these specimens were found identical with that of Angolan materials of $B$. asper, that being recharacterized by Bhatti (2002) based on its paratypes. Further, a comparative account of certain morphometric data (Table 1) of the materials collected during the present study also showed similarity with that of Angolan specimens as provided by Bhatti (2002). Such comparisons on morphometric measurements 


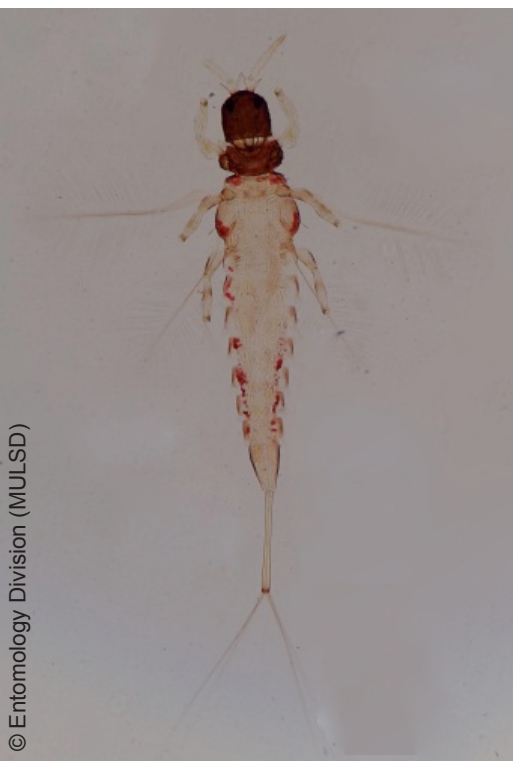

Image 1. Baenothrips asper

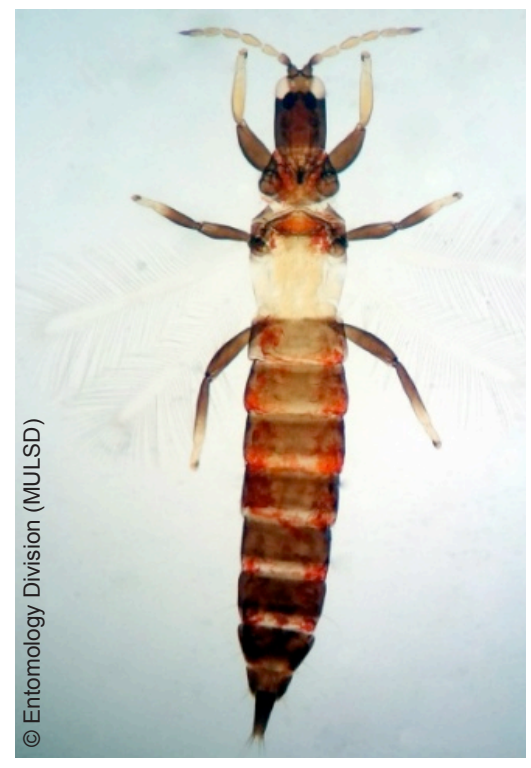

Image 2. Dyothrips pallescens

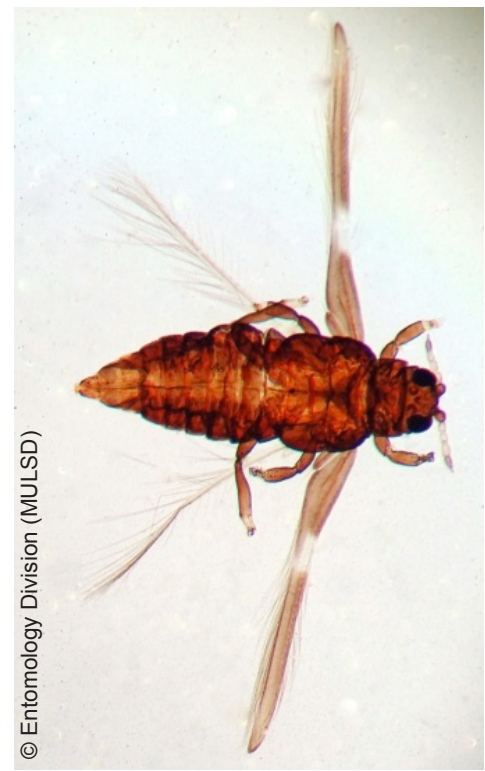

Image 3. Dendrothrips schimae and features of the winged form have clearly indicated that the specimens collected from Nagaland are $B$. asper. Thus, it becomes evident that the macropterous form of B. asper occurs in India besides the African continent and the present observation is the first of its kind to report its occurrence in the Indo-Myanmar Biodiversity Hotspot region of northeastern India.

\section{Dyothrips pallescens (Hood, 1919)}

Zygothrips pallescens Hood, 1919: Proc. Biol. Soc. Washington. 32: 75-92.

Dyothrips pallescens (Hood, 1919): Mound \& Minaei, (2007). J. Nat. Hist., 41: 2919-78.

Morphological features: Antennae 8 segmented; III with one sense cone; IV with 4 sense cones; Head longer than wide; body bicolourous; metathorax and abdominal segment I- yellow; rest brown. Prothoracic notopleural sutures incomplete. Fore wings without double fringes; all tarsi yellow, fore tarsi tooth absent. Post ocular and pronotal setae, and tergite IX setae S1 \& S2 expanded (Image 2).

Specimen studied: 1 male and 5 females, 18.vii.2010, Kangla (Manipur - new record); 750m, ex. Grass (Dichanthium annulatum (Forssk.) Stapf. (MU/LSD No. G T: 25).

Distribution: Australia, Bangladesh, China, Fiji, India (this report), Japan, Pakistan, Thailand, Taiwan.

\section{Suborder: Terebrantia}

Four species of terebrantians, viz., Dendrothrips schimae Kudo (1989), Mycterothrips consociatus (Targioni-Tozzetti, 1887), Panchaetothrips stepheni Reyes (1994), and Parabaliothrips coluckus (Kudo, 1977) (Thripidae) are collected in the present study.

\section{Dendrothrips schimae Kudo, 1989}

Dendrothrips schimae Kudo, 1989, Japanese Journal of Entomology 57(1): 42-45.

Dendrothrips schimae Kudo-Bhatti, 1990, Zoology

Table 1. Comparative morphometric data pertaining to Baenothrips asper

\begin{tabular}{|c|c|c|}
\hline Parameters & $\begin{array}{l}\text { Nagaland } \\
\text { specimen }\end{array}$ & $\begin{array}{l}\text { Angolan } \\
\text { specimen }^{* *}\end{array}$ \\
\hline Head- length/width & $144-160 / 152-160$ & $125-134 / 147-154$ \\
\hline $\begin{array}{l}\text { Cephalic setae length- } \\
\text { Median/Lateral }\end{array}$ & $64-72 / 48-56$ & $62-70 / 56-63$ \\
\hline $\begin{array}{l}\text { Antennal segment- length/ } \\
\text { width } \\
\text { I } \\
\text { II } \\
\text { III } \\
\text { IV } \\
\text { V } \\
\text { VI } \\
\text { VII } \\
\text { VIII }\end{array}$ & $\begin{array}{l}20-24 / 22-24 \\
32-40 / 28-32 \\
36-40 / 22 \\
36-40 / 24 \\
32 / 20-23 \\
28-32 / 16-20 \\
24-32 / 12-14 \\
20-24 / 8\end{array}$ & $\begin{array}{l}20-21 / 27-28 \\
36 / 30-32 \\
41-42 / 22 \\
37-38 / 25 \\
32-33 / 23 \\
30-32 / 20-21 \\
27-28 / 13-14 \\
23 / 8-9\end{array}$ \\
\hline Pronotum- length & $88-120$ & $92-94$ \\
\hline Epimeral setae-length & $24-32$ & 27 \\
\hline Tube-length & $300-336$ & $278-318$ \\
\hline
\end{tabular}

(All measurements are in $\mu,{ }^{* *}$ Bhatti 2002) 
2(4): 225.

Morphological features: Head irregularly reticulated between eyes, ocellar crescent red, cheeks with one moderately developed setae just on the lateral sides below eye. Antenna eight segmented. Forewings uniformly covered with microtrichia and banded. Pronotum transversely to slightly anastomosing striations. Abdominal segments II-VIII with two median setae, posterior marginal setae on IX strongly developed (Image 3).

Macropterous (female): Body dark brown with red pigments; abdominal segments pale at middle, legs brown except tarsi. Forewings brown with an incompletely formed light cross band, sub apex pale. Antennal segments 1, 2, 6-8 brown, 3-5 yellow.

Macropterous (male): Head ,thorax and abdominal segments V-VII brown, II-IV and VIII-X pale yellow. Forewing with a complete band with paler sub apex. All femora and tibiae brown, tarsi yellow.

Specimen studied: 5 females, 3 males, 5.ii.2001, Impur (Nagaland); 1350m, ex. Polygonatum multiflorum Allioni (Liliaceae) (MU/LSD No. B/ Weed/30).

Distribution: India (Nagaland-new record); earlier known only from Nepal.

\section{Mycterothrips consociatus (Targioni-Tozzetti, 1887)}

Thrips (Euthrips) consociatus Targioni-Tozzetti, 1887: Entomologica italiana 18(4): 419-431.

Mycterothrips consociatus (Targioni-Tozzetti, 1887): Masumoto \& Okajima (2006): Zootaxa 1261: 1-90.

Morphological features: Body pale; antennae Ipale, II-VIII uniformly brown (this character is unique for the present specimen); Antennae ratio: VI/(I-V) =1.2-1.45; Microtrichia absent on antennae VI; CPS absent on Mesonotum; Costal setae- 24-26; Upper vein- (6-7) +2; Lower vein setae- (9-10); Median pair of setae on mesonotum near posterior margin; Metascutum irregularly reticulate medially; median pair of setae near anterior margin; Sense cone on III \& IV not reaching the middle of its upper segment (Image 4).

Specimen studied: 8 males, 10.iv.2011, Moreh (Manipur - new record), 204m, ex. Bamboo foliage (small variety) (Poaceae) (MU/LSD No. M-T: 62).

Distribution: Austria, Czechoslovakia, Germany, Italy.

\section{Panchaetothrips stepheni Reyes, 1994}

Panchaetothrips stepheni Reyes, C.P. 1994. The Raffles Bulletin of Zoology 42: 107-507.

Panchaetothrips stepheni Kudo, I. 1995. Insecta Matsumurana, New Series 52: 81-103.

Morphological features: Body brown; Head entirely reticulate except on occipital collar; small setae present midway between the eye and hind ocellus. Reticles on the head posterior to the ocelli with wrinkles or markings; Sense cones on antennal segment IV forked while on III both simple and forked. Strong, stout long setae present on the wings. Antecostal lines on tergite III-VIII with weak posteriorly directed notches. Metanotum with an inverted triangle (Image 5).

Specimen studied: 1 female, 5.iv.2008, Moreh (Manipur - new record); 204m, ex. unidentified weed foliage (MU/LSD No. Weed/M-T: 67).

Distribution: Luzon, Philippine Islands.

\section{Parabaliothrips coluckus (Kudo, 1977)}

Krasibothrips coluckus Kudo, 1977, Kontyu, 45(1): 4-8. (Japan).

Krasibothrips coluckus Kudo: Ananthakrishnan and Sen, 1980, Zool. Surv. India. Handbk. Ser., 1: 69 \& 138.

Parabaliothrips coluckus (Kudo): Bhatti, 1990, Zoology 2(4): 244.

Morphological features: Body dark brown. Head little longer than wide, cheeks weakly serrated with 2-3 setae, vertex with two pairs of anteocellar setae, interocellar setae placed just behind ocellar triangle in line with posterior margin of hind ocelli. Antennal segments 3-4 with forked sense cones, 1, 2 brown, 3-5 yellow, 6 yellow at base, rest brown. Pronotum shorter than head, nearly rounded with exceptionally developed postangular setae, anteromarginal longer than anteroangular. Forewing brown with strongly developed setae, subbasal pale. All femora, mid and hind tibiae brown, all tarsi yellow. Comb on abdominal tergite VIII minute but complete; segments III-VII of males with transverse glandular areas, setae on IX exceptionally strong (Image 6).

Specimen studied: 5 females, 2 males, 31.ix.2000, Kohima (Nagaland), 1400m, ex. Quercus serrata (Thunb.) (Fagaceae); 8 females, 2 males, 24.viii.2001, Tengnoupal (Manipur), 1300m, ex. Q. serrata (Thunb.) (Fagaceae) (MU/LSD No. M-T: 68).

Distribution: Nepal, Taiwan, (India: Manipur \& 


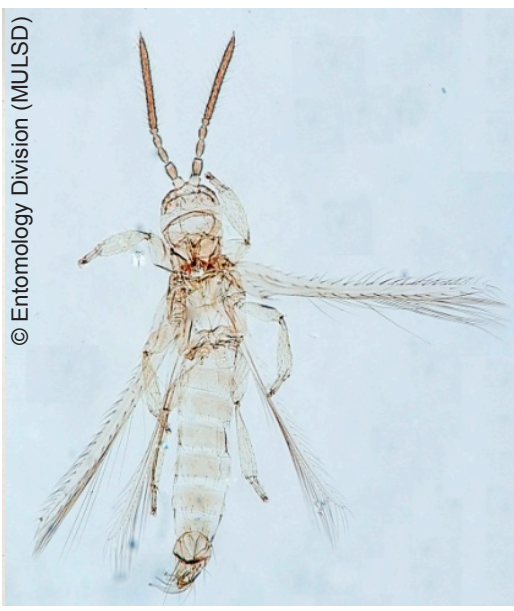

Image 4. Mycterothrips consociatus

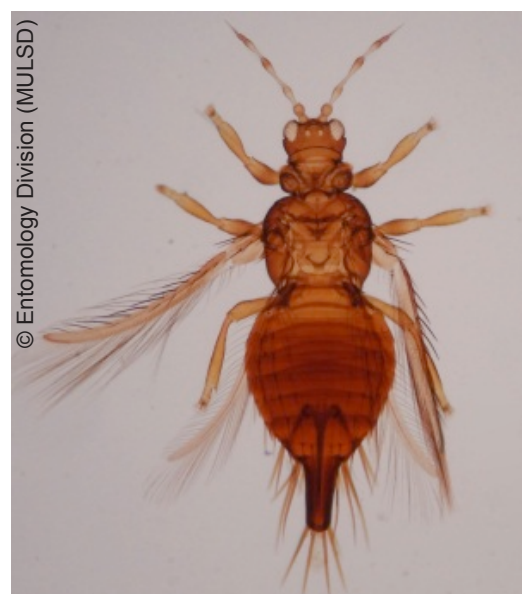

Image 5. Panchaetothrips stepheni

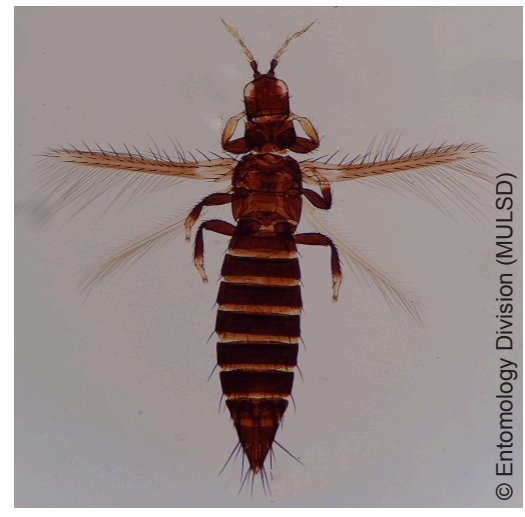

Image 6. Parabaliothrips coluckus
Nagaland - new record).

\section{REFERENCES}

Ananthakrishnan, T.N. (1966). Thysanopterologica indica IV. Bulletin of Entomology 7: 1-12.

Ananthakrishnan, T.N. \& S. Sen (1980). Taxonomy of Indian Thysanoptera. Handbook Series No.1. Zoological survey of India, $234 \mathrm{pp}$

Bhatti, J.S. (1990). Catalogue of insects of the Order Terebrantia from Indian subregion. Zoology 2(4): 205-352.

Bhatti, J.S. (1994). Phylogenetic relationships among Thysanoptera (Insecta) with particular reference to the families of the Order Tubulifera. Zoology (Journal of Pure and Applied Zoology) 4(1993): 93-130.

Bhatti, J.S. (2002). Identification of the Urothripid Baenothrips asper (Bournier, 1963) (Tubulifera: Urothripidae). Oriental Insects 36: 1-28.

Bournier, A. (1963). Thysanopteres de l'Angola, II. Publ. Cult. Comp. Diam. Angola 63: 75-86. (source: Bhatti, 2002).

David, B.V. \& T.N. Ananthakrishnan (2004). General and Applied Entomology (Second Edition). Tata McGraw-Hill Publishing Company Limited, New Delhi, 1184pp.

Hood, J.D. (1919). Two new genera and thirteen new species of Australian Thysanoptera. Proceedings of the Biological Society of Washington 32: 75-92. (source: Check list on
World Thysanoptera) < http://anic.ento.csiro.au/worldthrips/ taxon_search.asp>

Kudo, I. (1977). A new genus and two new species of Thripidae (Thysanoptera) from Nepal. Kontyu 45(1): 1-8.

Kudo, I. (1978). Some Urothripine Thysanoptera from eastern Asia. Kontyu 46(2): 169-175.

Kudo, I. (1989). Three species of Dendrothrips (Thysanoptera, Thripidae) from Nepal, with description of a new species. Japanese Journal of Entomology 57: 37-45

Kudo, I. (1995). Some Panchaetothrips from Nepal, Malaysia and the Philippines (Thysanoptera: Terebrantia: Thripidae). Insecta Matsumurana (New Series) 52: 81-103.

Masumoto, M. \& S. Okajima (2006). A revision of and key to the world species of Mycterothrips Trybom (Thysanoptera, Thripidae). Zootaxa 1261: 1-90.

Mound, L.A. \& K. Minaei (2007). Australian thrips of the Haplothrips lineage (Insecta: Thysanoptera). Journal of Natural History 41: 2919-2978.

Reyes, C.P. (1994). Thysanoptera (Hexapoda) of the Philippine Island. The Raffles Bulletin of Zoology 42: 107-507.

Targioni-Tozzetti, A. (1887). Notizie sommarie di due specie di Cecidomidei, una consocociata ad un Phytoptus, ad altri acari e ad una Thrips in alcune galle del Nocciola (Corylus avellana L.), una gregaria sotto la scorza dei rami di Olivi, nello stato larvale. Bollettino della Societa Entomologica italiana 18(4): 419-431. (source: world check list on thrips: http://anic.ento.csiro.au/worldthrips/taxon_search.asp). 